\title{
Entropy in the Canadian Economics Profession: Sampling Consensus on the Major Issues
}

\author{
WALTER BLOCK and MICHAEL WALKER* \\ The Fraser Institute
}

Il est généralement admis que les économistes ne s'accordent pas entre eux sur pratiquement toutes Tes questions relatives à leur profession. En effet, ce présumé phénomène est au coeur de nombreuses blagues à leur dépends. Toutefois, des recherches minutieuses ne confirment pas ce concept populaire. Sûrement il existe une grande diversité à l'intérieure de cette discipline académique concernant des questions de valeurs et d'éthiques. La même chose peut être aussi dite des opinions politiques d'autres professionnels. Dans tous les cas, lorsqu'il est question d'expertise technique, c'est-à-dire, l'économie positive opposće à l'économie normative, l'évidence révèle beaucoup moins de divergences dans les points de vue des praticiens canadiens. Dans l'ensemble, on a trouvé que les économistes au Canada étaient fort satisfaits du rôle du système des prix en tant que moyen d'allouer les ressources. Par exemple, seulement 3,8 pour cent de l'échantillon était en désaccord avec le principe que 'les tarifs et les quotas d'importation réduisent le bien-être économique général 'et seulement 4,7 pour cent ne sont pas d'accord avec l'affirmation qu' "un prix plafond sur les loyers réduit la quantité et la qualité de logements disponibles'.

It is widely assumed that economists differ with each other on virtually every issue of relevance to their profession. Indeed, this supposed phenomenon is at the core of numerous jokes at their expense. Careful research. however, does not bear out this popular perception. To be sure, there is a great diversity within this academic discipline concerning matters of values and ethics. But the same could be said with regard to the political opinions of other professionals. In any case, when it comes to matters of technical expertise, that is, positive economics as opposed to normative economics, the evidence shows much less divergence on the view of Canadian practitioners. On the whole economists in Canada were found to be quite appreciative of the role of the price system as a means of allocating resources and determining outcomes. For example, only 3.8 per cent of the sample disagreed with the view that 'Tariffs and import quotas reduce general economic welfare,' and only 4.7 per cent did not concur with the statement that 'A ceiling on rents reduces the quantity and quality of housing available'.

\section{Introduction}

$\mathrm{N}$ othing impairs the ability of economists to affect the course of practical affairs more than the common perception that they have widely varying opinions about almost everything, and a consensus about almost nothing. The consequence of this perception is that economists are frequently regarded as people with strong opinions and weak science.

While there can be no denying the widespread existence of this view, the basis for it has been subjected to very little rigorous analysis. An exception to this is the recent survey and analysis by Frey, Pommerehne, Schneider and Gilbert (1984) which probed the extent of consensus and dissension amongst economists in five countries: the United States, France, the Federal Republic of Germany, Austria and Switzerland. Their analysis was based on surveys conducted earlier by separate investigators in each of these nations.

Generally speaking, the results of this five country study provide an uncomfortable degree 
of support for the common prejudice about the views of economists. However, the questions about which there was least disagreement were those relating to the function of the price system, while most contention arose about those which in addition involved normative propositions about the conduct of economic policy.

The purpose of this paper is to replicate the survey experiment for Canadian economists in order to determine the extent of accord amongst them, the degree of difference between them and their colleagues in other countries, and also to examine whether there are systematic differences in our sample according to location, age, sex and level of education.

\section{The Sample Survey}

The questionnaire was sent to all 1,334 members of the Canadian Economics Association and the sample consists of the 479 who responded. Of those, 443 responses were actually usable in that they were complete, including the personal data section. (No follow-up mailing could be done because of the attempt to preserve double-blind conditions and the impossibility of knowing which of the members of the Association should be deleted in follow-up mailings.)

The respondents were asked, during the last quarter of 1986, to answer six questions of a personal nature relating to their age, sex, area of specialization, their employer, the location of their employer and the highest level of education they had completed. They were then asked either to generally agree, agree with provisions, generally disagree or not answer 27 questions relating to various aspects of economic theory and economic policy. ${ }^{1}$ Space was also provided to each of the respondents for any additional comment that they might wish to make. ${ }^{2}$

The form of questionnaire and the target group were dictated by the need to be consistent with the surveys completed in other countries. In particular, the four part response form was necessitated by the convention followed by others. (Several of the respondents claimed that the four part response choice was too limiting. $)^{3}$

\section{Characteristics of the Respondents}

The characteristics of the respondents are sum- marized in Table 1. There are 17 economic specialties reflected in the sample, 282 of the respondents were $\mathrm{Ph}$.D.-trained and about the same number were university teachers. Fewer than 25 per cent were employed by government (in non-academic positions) or by private industry. A vast majority, 360 , were more than 30 years of age. As could be expected, 298 or 62.2 per cent of the total resided in either Quebec or Ontario. Also not surprisingly, 95 per cent were males. In the next section we examine the extent of agreement amongst Canadian economists about 27 key propositions, and also look for elements - subsets of the answers - which seem to involve a higher degree of consensus. The fourth section examines the possibility that attitudes toward economic theory and policy are generational, regional, educational or genderrelated. In the fifth section we compare the responses of Canadian economists to those in other countries, and the final section provides some concluding comments.

\section{Where Economists Agree}

\section{Measures of Agreement or Disagreement}

Table 2 provides a summary of the responses to the questions posed and shows the extent to which there is consensus amongst the economists surveyed. Two different measures of convergence are reported, together with a ranking of the propositions according to their score on each. The first measure, and most obvious, is the simple frequency distribution of responses to the various questions.

By this simple measure, in 14 of the 27 questions there was a clear majority opinion in the sense that most of the respondents either generally agreed or generally disagreed with the proposition advanced. That means that in nearly half the cases there was no clear majority opinion amongst the respondents. Unfortunately, the simple majority rule criterion does not provide a very precise indicator of the extent of convergence that may exist on a particular issue. For example, if 50 per cent generally agree with the proposition, 25 per cent agree only with reservations, while 25 per cent disagree, that represents a different degree of consensus than if 50 per cent agreed, 1 per cent agreed with reservation 
Table 1

Distribution by characteristics of respondents

\begin{tabular}{|c|c|c|c|}
\hline \multicolumn{2}{|l|}{ Age } & \multicolumn{2}{|l|}{ Employer } \\
\hline Under 30 & 83 & Junior or 2 year College & 10 \\
\hline Over 30 & 360 & $\begin{array}{l}4 \text { year College } \\
\text { University }\end{array}$ & $\begin{array}{r}17 \\
287\end{array}$ \\
\hline Sex & & Research Institute & 29 \\
\hline Male & 420 & Other & 100 \\
\hline Female & 23 & Location of employer, by province & \\
\hline Field of specialization & & Newfoundland & 2 \\
\hline Micro economics & 60 & Prince Edward Island & 1 \\
\hline Macro economics & 53 & Nova Scotia & 22 \\
\hline International economics & 50 & New Brunswick & 8 \\
\hline Public Finance & 49 & Quebec & 90 \\
\hline Industrial organization & 42 & Ontario & 208 \\
\hline Econometrics & 38 & Manitoba & 12 \\
\hline Monetary economics & 35 & Saskatchewan & 12 \\
\hline Labour economics & 35 & Alberta & 40 \\
\hline Natural resources & 32 & British Columbia & 48 \\
\hline Development economics & 15 & & \\
\hline Economic history & 13 & Highest level of education completed & \\
\hline Miscellaneous & 21 & $\begin{array}{l}\text { Ph.D. } \\
\text { A.B.D. } \\
\text { Masters } \\
\text { Bachelors }\end{array}$ & $\begin{array}{r}282 \\
43 \\
103 \\
15\end{array}$ \\
\hline
\end{tabular}

and 49 per cent disagreed. In order to capture the dispersion of opinion we have therefore calculated a measure of discordance referred to as the relative entropy parameter. ${ }^{4}$

The relative entropy parameter is a measure of the extent to which the dispersion of responses approximates what the dispersion would be if there were a completely random pattern of response. Accordingly, if there were no analytical structure in common amongst the respondents to the questions, there would be a random pattern of replies or 25 per cent in each of the four possible response categories. That pattern would be the maximum entropy possible in the system, and the extent of entropy actually realized is calculated relative to that maximum. In order to provide a parameter which ranges from zero to one, the frequencies are weighted by the $\log$ of the frequencies. This yields a relative entropy parameter which ranges from zero for complete agreement to one for complete disagreement. $^{s}$

We have also ranked the responses according to the strength of the dominant response, whether 'agree' or 'disagree,' to provide an independent measure of consensus. We call this the unanimity ranking.
Views about the Price System

A perusal of the relative entropy calculations for the 27 questions provides considerable support for the view that Canadian economists have a great deal of disagreement about virtually every issue that they are asked to address. As in the international sample mentioned above, the extent of this disagreement is less pronounced in those areas which specifically involve an assessment of the price system. Thus, for example, question 1 (tariffs and quotas), question 5 (flexible exchange rates), question 7 (on the relationship between minimum wages and unemployment), question 14 (on the efficacy of wage and price controls) and question 15 (on the effect of rent control on the supply and quality of rental accommodations) show the lowest entropy or the highest degree of consensus amongst economists. They also show the highest degree of unanimity in the sense that more people selected the polar response for these propositions than for any of the others.

There seems to be agreement that the price mechanism does an adequate job of allocating resources, and to that extent is an effective and desirable mechanism of social choice. This view is also reflected in the rejection of government as 
Table 2

Propositions and responses, Canadian economists

Propositions

Responses

(per cent)
Relative

entropy
Ranking by:

Relative entropy Unanimity
1. Tariffs and import quotas reduce general economic welfare

2. The government should be an employer of last resort and initiate a guaranteed job program

3. The money supply is a more important target than interest rates for monetary policy

4. Cash payments are superior to transfers-in-kind

5. Flexible exchange rates offer an effective international monetary arrangement

6. The 'Corporate State' as depicted by Galbraith accurately describes the context and structure of advanced economies

7. A minimum wage increases unemployment among young and unskilled workers

8. The government should index the income tax rate structure for inflation

9. Fiscal policy has a significant stimulative impact on a less than fully employed economy

10. The distribution of income in the developed industrial nations should be more equal

11. Antitrust laws should be used vigorously to reduce monopoly power from its current level

12. Inflation is primarily a monetary phenomenon

13. The government should restructure the welfare system along lines of a 'negative income tax'

14. Wage-price controls should be used to control inflation

15. A ceiling on rents reduces the quantity and quality of housing available

16. The central bank should be instructed to increase the money supply at a fixed rate

17. Effluent taxes represent a better approach to pollution control than imposition of pollution ceilings
A 70.2

B 25.7

C $\quad 3.8$

A 14.0

B 24.2

C 60.9

A 31.8

B 26.0

C 39.7

A 55.1

B 30.2

C 12.4

A 57.6

B $\quad 35.9$

C $\quad 5.9$

A 13.3

B 36.1

C 43.8

A 68.2

B 16.9

C 14.7

A 68.4

B 18.3

C 12.9

A 46.7

B 38.1

C 14.2

A 35.2

B 31.8

C 29.3

A 33.4

B 38.4

C 26.9

A 42.4

B 32.3

C 23.5

A $\quad 51.9$

B $\quad 35.4$

C 11.1

A 4.5

B 21.4

C 72.9

A 80.4

B 14.4

C $\quad 4.7$

A 13.5

B 29.1

C 54.9

A 48.5

B 32.3

C 17.4
.53

.69

.85

21

22

.75

12

10

.64

.85

23

18

.62

4

5

5

4

.75

13

24-25

.82

19

19-20

2

.45

1

.76

14

11

.79

\section{3}

7

8

18

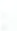

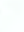


Table 2 contd.

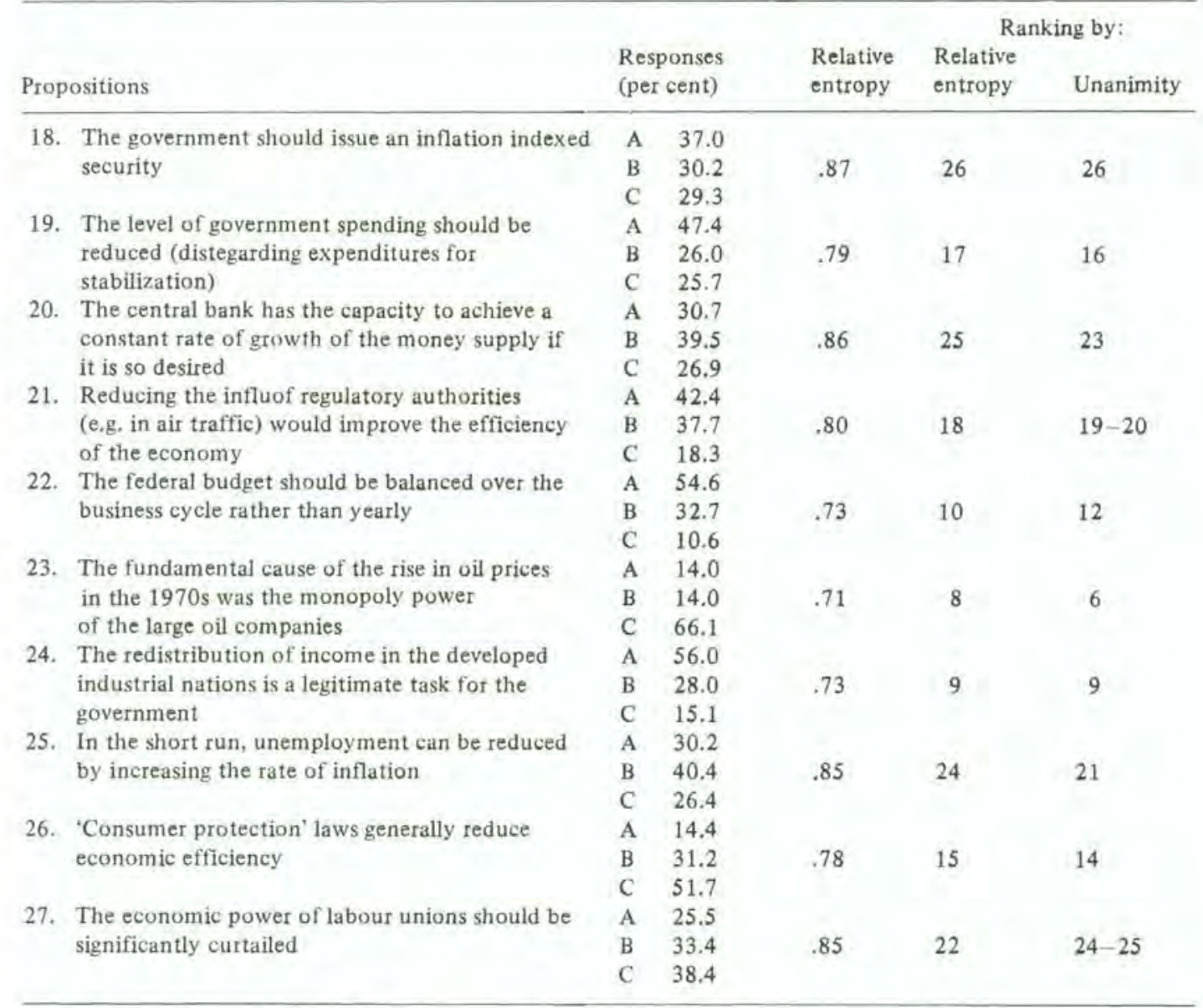

Notes: $N=443 . A=$ Generally agree; $B=$ Agree with provisions; $C=$ Generally disagree.

The responses do not sum to $100 \%$ as the 'No Answer' category is not listed.

the employer of last resort (question 2) and agreement that the level of government spending should be reduced (question 19) and that reducing the influence of regulatory authorities (question 21) would improve the efficiency of the economy.

However, based on a perusal of their answers to questions 11,26 and 27, a sizeable part of our sample of economists would appear to take the position that 'market failure' can and indeed does occur in the Canadian setting. Over a quarter of respondents supported the vigorous use of anti-trust (anti-combines) legislation, over half took the view that consumer protection laws increase efficiency, ${ }^{6}$ and slightly less than 40 per cent opposed the significant curtailment of union power.

\section{Canadian Keynesian}

There is a strong consensus that the government budget should be balanced over the cycle (question 22), with 80 per cent of the respondents either agreeing or agreeing with reservation. Also, 78 per cent agree or agree with reservation that fiscal policy does in fact stimulate the economy (question 9). However, on this issue there was more consensus than unanimity. (The entropy ranking of this proposition was 9 while 
the unanimity ranking was 17.) That acceptance, together with the rejection, by a slim majority, of the establishment of a money supply rule (question 16), suggests that the average Canadian economist is more inclined to be a Keynesian than a monetarist in public policy attitudes. This picture is blurred somewhat, however, for a majority agreed or agreed with reservation that money supply was a more important target for monetary policy (question 3 ).

On the other hand, there is also strong support for propositions associated with Milton Friedman. For example, there was general approval for the indexation of the tax system (question 8), the adoption of a negative income tax (question 13 ) and the government provision of an inflation indexed security (question 18).

\section{Specific Issues}

In the case of proposition 1, 'Tariffs and import quotas reduce general economic welfare,' 70 per cent generally agreed and only 3.8 per cent generally disagreed. This conveys the impression of a high degree of uniformity amongst economists about the efficacy of freer trading arrangements in improving general economic welfare. When we also include those who generally agreed but with some reservation, the total is boosted considerably. In fact, 96 per cent of economists generally agreed or agreed with some reservation to the proposition that tariffs and import quotas reduce general economic welfare.

Nearly 24 per cent rejected the proposition that inflation is primarily a monetary phenomenon (question 12), while 44 per cent of the respondents rejected Galbraith's corporate state view (question 6).

The majority of the respondents agreed or agreed with reservation that in the short term the rate of unemployment can be reduced by increasing the inflation rate (question 25) - an acceptance of the existence in the short run of a trade off between inflation and unemployment.

A majority accepted the notion that redistribution of income is a legitimate task for modern governments. This outcome is compatible with the opinion held by just over 60 per cent of the respondents that the distribution of income should be more equal.

\section{Normative versus Positive Issues}

It is often said that the perception of disagreement amongst economists arises from differences about normative issues in that economists who agree on the basic technical issues about the operation of the economy part company when it comes to normative questions involving policy direction. While, as Milton Friedman points out in his classic statement (1953:5), disagreements about policies frequently emerge simply because of a difference in the expectation people have about the effect of policy actions taken, policy disagreements may also relate to the objectives of the policy. In an attempt to determine whether there is a difference in entropy between normative and positive propositions, James Kearl et al. (1979:33) arranged the propositions in Table 1, at least those which lend themselves to taxonomy, according to the categories 'micro can,' 'micro should,' 'macro can' and 'macro should'. We have followed their taxonomy in the following tests.

The 'micro can' category included tariffs (question 1), cash versus in-kind transfers (question 4), flexible exchange rates (question 5), minimum wage (question 7), rent ceiling (question 15) and effluent taxes (question 17). "Micro should' included anti-trust laws (question 11), regulation and efficiency (question 21), consumer protection (question 26) and union power (question 27). 'Macro can' included money versus interest rate targets (question 3 ), fiscal policy stimulus (question 9), inflation as a monetary phenomenon (question 12), money rule is achievable (question 20) and Phillip's curve (question 25). In 'macro should' are placed employer of last resort (question 2), indexed taxes (question 8), negative income tax (question 13), pursuing money rule (question 16 ), index security (question 18) and budget balance (question 22). ${ }^{7}$

In their study for the United States, Kearl et $a l$. found a significantly higher degree of agreement on positive than on normative questions, and on micro than on macro propositions. No such differences emerge in the Canadian data. In an analysis of the variance of the entropy parameter within and between the sub-samples, an $F$ test does not reject the null hypothesis that the same population generated the entropy ob- 
served in micro/macro and can/should bifurcations of the data. ( $F$ values of 2.05 and .87 for micro/macro, can/should respectively, each with 1 and 19 degrees of freedom.) In this respect, Canadian economists appear to reflect the same sort of entropy noted by Frey et al. for European economists.

\section{Responses by Type of Respondent}

\section{Sex}

The responses to the questions were different for sub-groups with different characteristics. Consider gender first. Using the chi-square statistic to analyse the response frequencies of the subgroups, we found that there is a significant difference between the response patterns of males and females in six of the questions posed specifically, question 1 (free trade), question 6 (Galbraith depiction of the corporate state), question 8 (indexation of the income tax structure), question 15 (effects of rent control), question 19 (on whether or not the level of government spending should be reduced) and question 22 (on whether the federal budget should be balanced over the business cycle rather than yearly).

Differences in response frequencies do not necessarily indicate difference of opinion amongst those who have a firm view. We observed that 42 per cent of the female respondents thought Galbraithian analysis of the corporate state was an accurate depiction of advanced economies, while 49 per cent of males agreed or agreed with some reservation that Galbraith's analysis was descriptive. The really important difference between males and females was the higher failure to respond rate. In the case of women, this was 26 per cent of respondents versus 6 per cent in the case of men. (Perhaps this difference is because non-respondents had simply not read the material about which the question was asked. They are typically younger, while Galbraith enjoyed a greater readership in the 1960 s than at present.)

The sharpest difference in views between males and females was registered on the issue of free trade. A chi-square value of 17.97 for this question leaves it very unlikely that the male and female opinions came from the same population:
71.9 per cent of males agreed without reservation that tariffs and quotas reduced economic welfare, whereas only 39 per cent of women held this view; 17.4 per cent of women disagreed with this proposition, as compared with only 3 per cent of males. ${ }^{8}$

Age

Age does not appear to be a significant determinant of the opinion of economists except in three areas where the chi-square statistic indicates significant difference between the group under 30 and the group over 30 . The three areas were (question 3) money is a more important target than interest rates for a monetary policy, (question 4) cash payments are superior to transfers in kind and (question 19) that the level of government spending should be reduced. Oddly enough, in view of the historical pattern of theoretical development, the response to question 3 indicates that those who are less than 30 years of age are less likely to be monetarists. Neither group was particularly receptive to the idea, but 60 per cent of the over- 30 group (compared to 46 per cent of the under-30 group) either agreed or agreed with reservation with the proposition that the money supply is a more important target than interest rates. An equally surprising result was that the under- 30 group also rejected, in 23 per cent of the cases, the proposition that cash payments are superior to transfers in kind, while only 10 per cent of the over- 30 group did. The younger economists also displayed a stronger predilection to reduce the size of government, with 83 per cent accepting or accepting with reservation the notion that the level of government spending ought to be reduced, whereas only 71 per cent of the over- 30 group agreed with that proposition.

\section{Education}

Of all the characteristics specifically identified on the questionnaire, the one that produces the most dissimilar sub-groupings is the educational attainment level. For example, by splitting the total sample into two groups, those with a Ph.D. (282) and those without (161), it was found that in ten of the questions it could not be assumed that the sub-groups came from the same population. Ph.D.s were more likely to accept free 
Table 3

Responses to the propositions, individual countries

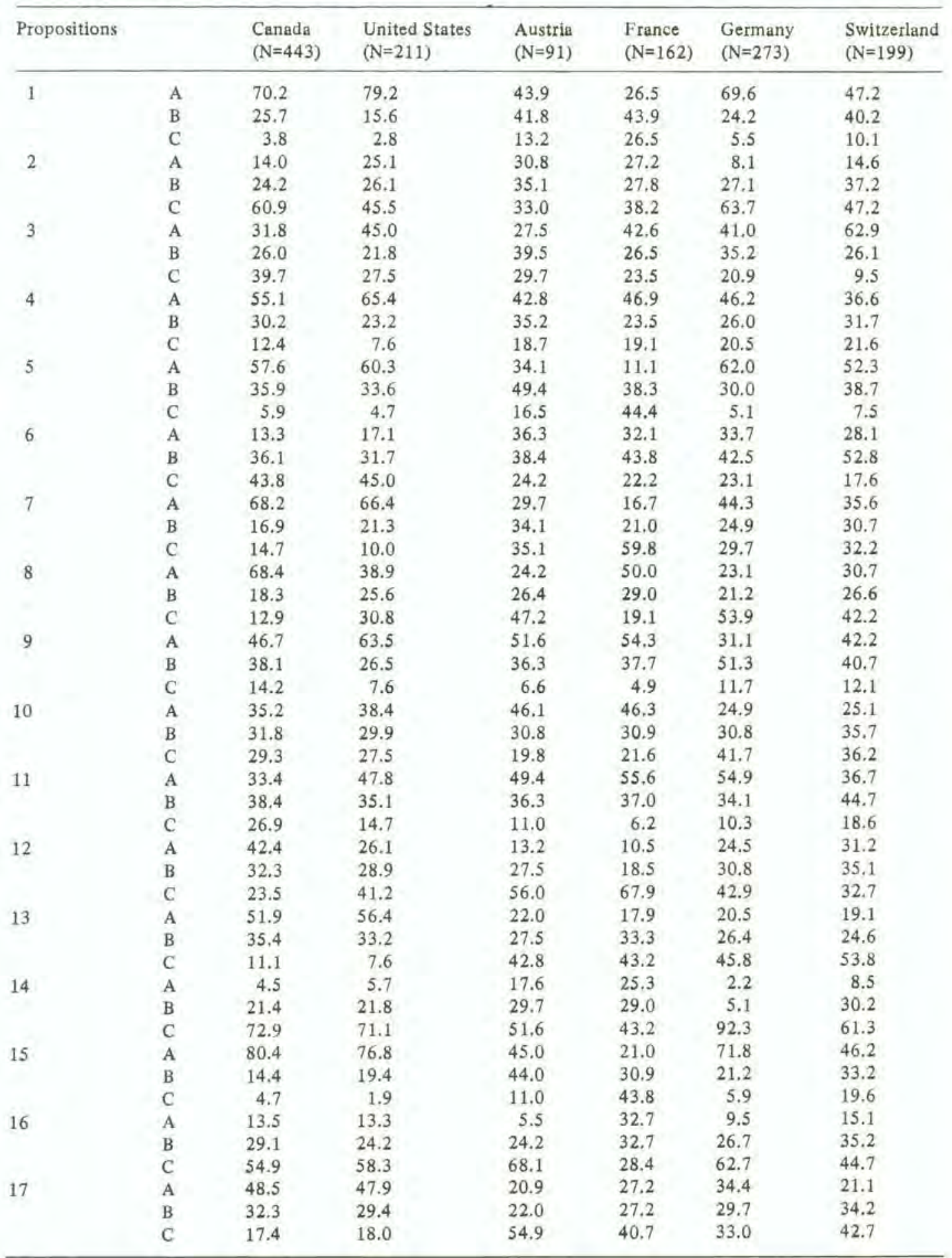


Table 3 contd.

\begin{tabular}{|c|c|c|c|c|c|c|c|}
\hline Propositions & & $\begin{array}{l}\text { Canada } \\
(\mathrm{N}=443)\end{array}$ & $\begin{array}{l}\text { United States } \\
(\mathrm{N}=211)\end{array}$ & $\begin{array}{l}\text { Austria } \\
(\mathrm{N}=91)\end{array}$ & $\begin{array}{l}\text { France } \\
(\mathrm{N}=162)\end{array}$ & $\begin{array}{l}\text { Germany } \\
(\mathrm{N}=273)\end{array}$ & $\begin{array}{l}\text { Switzerland } \\
(\mathrm{N}=199)\end{array}$ \\
\hline \multirow[t]{3}{*}{18} & A & 37.0 & 30.8 & 20.9 & 33.3 & 15.4 & 19.1 \\
\hline & B & 30.2 & 23.2 & 24.2 & 25.3 & 22.7 & 26.1 \\
\hline & C & 29.3 & 39.4 & 52.7 & 37.7 & 60.1 & 50.8 \\
\hline \multirow[t]{3}{*}{19} & A & 47.4 & 32.2 & 42.8 & 32.1 & 48.8 & 38.7 \\
\hline & B & 26.0 & 21.8 & 25.3 & 26.5 & 30.4 & 32.7 \\
\hline & C & 25.7 & 40.8 & 30.8 & 37.1 & 20.1 & 27.1 \\
\hline \multirow[t]{3}{*}{20} & A & 30.7 & 33.2 & 14.3 & 14.8 & 18.7 & 32.7 \\
\hline & B & 39.5 & 38.9 & 40.6 & 41.4 & 49.8 & 50.2 \\
\hline & C & 26.9 & 22.7 & 40.7 & 40.1 & 30.0 & 14.1 \\
\hline \multirow[t]{3}{*}{21} & A & 42.4 & 45.0 & 22.0 & 15.4 & 30.8 & 27.6 \\
\hline & B & 37.7 & 29.9 & 34.1 & 21.6 & 44.3 & 34.2 \\
\hline & $\mathrm{C}$ & 18.3 & 20.9 & 42.8 & 56.2 & 23.1 & 36.2 \\
\hline \multirow[t]{3}{*}{22} & A & 54.6 & 50.7 & 70.3 & 44.4 & 50.3 & 65.4 \\
\hline & B & 32.7 & 28.5 & 18.7 & 30.2 & 28.9 & 26.1 \\
\hline & C & 10.6 & 16.1 & 8.8 & 19.8 & 20.1 & 8.0 \\
\hline \multirow[t]{3}{*}{23} & A & 14.0 & 10.4 & 16.5 & 8.6 & 5.5 & 10.1 \\
\hline & B & 14.0 & 13.3 & 28.6 & 15.4 & 20.5 & 31.7 \\
\hline & C & 66.1 & 71.6 & 53.8 & 73.5 & 73.3 & 58.2 \\
\hline \multirow[t]{3}{*}{24} & A & 56.0 & 50.2 & 58.2 & 56.8 & 40.2 & 39.2 \\
\hline & B & 28.0 & 28.0 & 29.7 & 30.9 & 38.5 & 31.2 \\
\hline & C & 15.1 & 18.5 & 11.0 & 11.1 & 20.9 & 27.6 \\
\hline \multirow[t]{3}{*}{25} & A & 30.2 & 29.4 & 36.3 & 19.1 & 27.8 & 33.2 \\
\hline & B & 40.4 & 31.3 & 36.2 & 34.0 & 33.0 & 37.2 \\
\hline & C & 26.4 & 34.1 & 25.3 & 42.6 & 38.8 & 28.1 \\
\hline \multirow[t]{3}{*}{26} & A & 14.4 & 23.2 & 6.6 & 4.9 & 10.3 & 18.1 \\
\hline & B & 31.2 & 27.0 & 22.0 & 16.7 & 24.2 & 25.6 \\
\hline & C & 51.7 & 46.0 & 70.3 & 77.2 & 65.1 & 55.8 \\
\hline \multirow[t]{3}{*}{27} & A & 25.5 & 30.8 & 17.6 & 19.1 & 20.9 & 18.6 \\
\hline & B & 33.4 & 37.0 & 28.6 & 22.2 & 34.8 & 28.1 \\
\hline & C & 38.4 & 28.9 & 52.7 & 54.4 & 43.6 & 51.3 \\
\hline
\end{tabular}

trade vigorously, to be monetarist in their attitude toward monetary policy, to accept the superiority of transfers in cash rather than in kind, to reject the Galbraithian view of the world, to believe that minimum wage laws increase unemployment, that tax structures should be indexed for inflation and that rent controls reduce the quantity and quality of rental accommodation available. Ph.D.s were less likely to believe that the fundamental cause of the rise in oil prices was the monopoly power of large oil companies. However, the Ph.D. group was also less likely to believe that the level of government spending should be reduced. Only 68 per cent of Ph.D.s agreed or agreed with provisions to this statement, whereas fully 80 per cent of the others agreed.
Because of the striking differences between the respondents according to educational attainment and the previously observed difference between males and females on the issue of the effect of tariffs and quotas, a cross tabulation of females by educational attainment was computed. This exercise reveals that the difference between males and females is not attributable to educational level. In fact the response frequency for females to question 1 was almost identical for Ph.D.s and non-Ph.D.s. In each case about 40 per cent agreed that tariffs and quotas would reduce general economic welfare.

A characteristic which seemed to have no effect at all on the views of economists was their geographical location. Only in one case did the chi-square statistic register a level of significant 
difference between the economists living in Ontario and Quebec and those living in the rest of the country. This was on the question of whether or not there exists a short-run trade off, between inflation and unemployment. On further examination it was discovered that there was no difference in the belief in the existence of the trade off, but only in the strength of the belief.

\section{International Comparisons}

\section{Canada and Europe}

It is interesting to compare the results for the Canadian sample with the opinions of economists in other countries (see Table 3 ). We have made comparisons between Canada and the United States and Canada and the collective results from France and Austria, which were grouped together by Frey et al. as being a distinctive group of economists in the European context. It is important to note in this comparison that the surveys were not conducted at the same point in time. The American survey results were published in 1979, whereas those for Europe appeared in the early 1980s. Some of the differences discovered in the data may therefore reflect the effects of changes in global attitudes.

Two questions are of interest in examining the similarities and differences in opinion between economists in the different countries. First of all, there is the question of whether the responses to specific propositions are similar in different countries. The second question of interest is whether the extent of consensus within countries differs across countries.

There are striking differences between the opinions of economists in different countries. For example in the proposition-by-proposition comparison between Canada and the collected France and Austria sample, chi-squared values of significant levels were discovered in 26 out of 27 cases, and some of the chi-squared values ranged as high as 145 .

In general, French economists seem to have very little regard for the allocative power of markets and a great deal of confidence in the economic efficiency of regulation and a broader government presence in the economy. This was true also to a somewhat lesser degree, of the economic opinions expressed by Austrian econ- omists with whom they are aggregated in the Canada/European comparison. Fully 59.8 per cent of the French economists surveyed believe that a minimum wage law does not increase unemployment among young and unskilled workers and that nearly a majority at 43.8 per cent disagreed that a ceiling on rents reduces the quantity and quality of housing available is indicative of the sort of responses contained in the French data.

The sharp disagreement of French economists with propositions that would seem to follow ineluctably from simple supply and demand modelling calls into question the very taxonomy of economists. That is to say, one might set out to determine who is an economist and who is not an economist on the basis of his/her response to certain fundamental questions relating to economic science. It is perhaps no accident that French economists are referred to less on government policy questions than are officers from the elite national schools. This may also be true in the USSR where 'economists' are often similar to economic geographers, and economic thinking - or what passes for this in that country - tends to be left to government systems analysts.

The extent of the variation in opinion between the economists of the various countries can be gathered from Tables 3 and 4 . Table 4 contains the entropy calculations for each of the countries along with the ranking by entropy level. As can be seen, the questions about which there is most agreement in Canada, the US and Germany are often in great dispute elsewhere. In only two cases do the top five ranked questions (question $1,5,7,14,15)$ in Austria and France coincide with the top five ranked in the US and Canada (questions 14, 15).

The differences and similarity between Canada and the other country samples is further highlighted in the pair-wise rank correlation coefficients which are shown in Table 5 . The highest correlation is between Canada and the United States, while the correlation between Canada and France is the weakest.

While the opinions expressed by French and Austrian economists are very different from those expressed by Canadians, there does not appear to be a significant degree of difference 
Table 4

Entropy and ranking, individual countries

\begin{tabular}{|c|c|c|c|c|c|c|c|c|c|c|c|c|}
\hline \multirow[b]{2}{*}{ Propositions } & \multicolumn{2}{|c|}{ Canada } & \multicolumn{2}{|c|}{ United States } & \multicolumn{2}{|c|}{ Austria } & \multicolumn{2}{|c|}{ France } & \multicolumn{2}{|c|}{ Germany } & \multicolumn{2}{|c|}{ Switzerland } \\
\hline & Ent. & Rank & Ent. & Rank & Ent. & Rank & Ent. & Rank & Ent. & Rank & Ent. & Rank \\
\hline 1 & .53 & 2 & .48 & 1 & .75 & 8 & .85 & 16 & .57 & 4 & .75 & 7 \\
\hline 2 & .69 & 7 & .84 & 15 & .83 & 21 & .91 & 26 & .65 & 6 & .76 & 9 \\
\hline 3 & .85 & 21 & .87 & 21 & .86 & 26 & .90 & 25 & .84 & 23 & .67 & 4 \\
\hline 4 & .75 & 12 & .68 & 8 & .83 & 24 & .90 & 24 & .88 & 26 & .93 & 27 \\
\hline 5 & .64 & 6 & .63 & 4 & .73 & 6 & .83 & 14 & .66 & 7 & .70 & 5 \\
\hline 6 & .85 & 23 & .86 & 18 & .81 & 18 & .82 & 12 & .80 & 17 & .77 & 10 \\
\hline 7 & .62 & 4 & .66 & 6 & .83 & 20 & .74 & 7 & .81 & 19 & .84 & 22 \\
\hline 8 & .62 & 5 & .88 & 24 & .82 & 19 & .79 & 8 & .77 & 13 & .80 & 15 \\
\hline 9 & .75 & 14 & .67 & 7 & .76 & 9 & .69 & 5 & .81 & 20 & .82 & 16 \\
\hline 10 & .87 & 27 & .88 & 23 & .83 & 23 & .80 & 9 & .84 & 24 & .86 & 26 \\
\hline 11 & .83 & 20 & .79 & 11 & .77 & 13 & .66 & 4 & .70 & 9 & .75 & 8 \\
\hline 12 & .82 & 19 & .86 & 19 & .76 & 12 & .66 & 3 & .82 & 22 & .82 & 19 \\
\hline 13 & .73 & 11 & .71 & 9 & .90 & 27 & .86 & 19 & .88 & 27 & .78 & 11 \\
\hline 14 & .54 & 3 & .58 & 3 & .76 & 11 & .84 & 15 & .24 & 1 & .63 & 2 \\
\hline 15 & .45 & 1 & .48 & 2 & .69 & 4 & .86 & 18 & .57 & 3 & .79 & 12 \\
\hline 16 & .76 & 13 & .76 & 10 & .61 & 2 & .91 & 27 & .66 & 8 & .84 & 23 \\
\hline 17 & .79 & 16 & .84 & 14 & .77 & 14 & .88 & 23 & .86 & 25 & .82 & 17 \\
\hline 18 & .87 & 26 & .90 & 27 & .79 & 15 & .87 & 20 & .72 & 10 & .82 & 18 \\
\hline 19 & .79 & 17 & .88 & 22 & .81 & 17 & .88 & 22 & .77 & 12 & .83 & 20 \\
\hline 20 & .86 & 25 & .88 & 25 & .83 & 22 & .82 & 13 & .78 & 15 & .79 & 14 \\
\hline 21 & .80 & 18 & .85 & 17 & .80 & 16 & .81 & 11 & .82 & 21 & .84 & 25 \\
\hline 22 & .73 & 10 & .82 & 13 & .62 & 3 & .87 & 21 & .77 & 11 & .62 & 1 \\
\hline 23 & .71 & 8 & .64 & 5 & .75 & 7 & .59 & 2 & .54 & 2 & .66 & 3 \\
\hline 24 & .73 & 9 & .81 & 12 & .70 & 5 & .71 & 6 & .78 & 14 & .84 & 24 \\
\hline 25 & .85 & 24 & .90 & 26 & .84 & 25 & .85 & 17 & .80 & 18 & .83 & 21 \\
\hline 26 & .78 & 15 & .85 & 16 & .58 & 1 & .50 & 1 & .63 & 5 & .73 & 6 \\
\hline 27 & .85 & 22 & .87 & 20 & .76 & 10 & .81 & 10 & .79 & 16 & .79 & 13 \\
\hline
\end{tabular}

Note: In the event of a tie, ranked by 3 rd or 4 th decimal.

between Canadian, French and Austrian economists in the extent to which they disagree with their countrymen. This is measured by calculating the $F$ statistic for the dispersion of the entropy calculations in the countries. Of the various combinations tested and reported in Table 6, the only significant difference found was between the extent of consensus in Canada and France where an $F$ value of 3.5 is sufficiently high as to make it improbable (at the 10 per cent level) that the entropy samples in the two countries were generated by the same population.

\section{Canada and the United States}

For Canadian readers, the most important comparison is of course between Canadian and US economists. On this score the results are quite fascinating. First of all, there seems to be no great difference in the extent of agreement between Canadian and US economists. That is to say, the extent of consensus in the two countries, as measured by the entropy parameter for the 27 propositions advanced, is not dissimilar enough to be reflected in a significant $F$ statistic. Moreover, as seen in Table 5, the coincidence of consensus on the various propositions is also quite high in that there is a .65 correlation between the two rankings.

On the other hand, the actual responses to the individual questions, comparing frequency against frequency, were quite different and yielded significant (greater than 9.48) chi-squared statistics in ten cases. An examination of the propositions which are flagged by the chi-squared statistic yields some very interesting impressions 
Table 5

Rank correlation

\begin{tabular}{llllll} 
& United States & Austria & France & Germany & Switzerland \\
\hline Canada with & .788 & .389 & .110 & .474 & .317 \\
\hline
\end{tabular}

about the opinions of Canadian and US economists. (Statistically significant differences in response frequencies were found in the following propositions: $1,2,3,7,8,9,11,12,18,19$.)

While both are concerned about the economic impact of tariffs and import quotas, Americans are slightly more convinced that they reduce general economic welfare. On the other hand, they are less opposed than Canadians to the proposition that governments should be an employer of last resort and initiate a guaranteed job program; 61 per cent of Canadian economists rejected this notion absolutely, whereas only 45,5 per cent of Americans did so. In other words, a slim majority of US economists are in favour or in favour with reservation of the government being an employer of last resort and initiating a guaranteed job program.

An examination of the other flagged questions in Tables 3 and 4 indicates that Canadian economists are more supportive of the price mechanism than Americans. A higher proportion of Canadians tend to support propositions related to market function, such as the impact of minimum wages, rent controls and the like. Canadian economists also tend to be more monetarist and less Keynesian in their analytical predisposition. Fewer tend unreservedly to accept the notion that fiscal policy has a significant stimulative impact on a less than fully employed economy. The per centage of Canadian economists categorically rejecting this, at 14 per cent, was twice that in the US.

Canadians also seem to have a stronger disposition to reduce the level of government spending apart from those expenditures needed for stabilization purposes. Of the Canadian economists surveyed, 73 per cent felt that the level of government expenditures ought to be reduced, whereas only 53 per cent of the American economists surveyed held this view. Somewhat fewer Canadian economists find
Table 6

Testing intercountry entropy variation

\begin{tabular}{lc}
\hline Countries & F statistic \\
\hline Canada-France & 3.502282 \\
Canada-Austria & 1.090745 \\
Austria-France & 1.3740356 \\
Canada-US & .835874 \\
\hline
\end{tabular}

wage and price controls efficacious or believe that inflation is primarily a monetary phenomenon, and fewer believe that anti-trust laws should be used to reduce monopoly power.

While the opinions of Canadian economists seem to favour the market more strongly in almost every instance and to favour what might be broadly referred to as a conservative position on policy issues, that does not extend to what would be regarded as the more telling issue in the normative distinction between those on the left and right of the political spectrum, namely, on the appropriateness of government involvement in the redistribution of income. A higher percentage of Canadian respondents support such activity than those in the United States, although the differences in the percentages were not significant.

\section{Summary and Conclusions}

The analysis contained in this paper provides support for the general perception that economists are mixed in their opinions on important issues, and that there is wide dispersion of firmness of view, even on those issues where there is a measure of agreement about the general direction of the outcome. Nevertheless, on the whole, Canadian economists seem to be quite supportive of the price mechanism as an allocative device and convinced of the powers of market forces in determining outcomes. The 
more highly educated the economist, the more likely he or she was to accept the role of markets.

While Canadians seem to be enamoured of government directed redistribution of income, they do not appear to accept the current high levels of government expenditure and would reduce them. They are not as inclined as American and European economists to accept Keynesian propositions regarding the stabilization function of government. An astoundingly high 97 per cent of Canadian economists accepted the view that tariffs and quotas reduced the general level of welfare.

A surprising result is the discovery that on the whole Canadian economists seem less disposed to support interventionist policy than are their American counterparts. This was particularly true of the proposition relating to the role of government as an employer of last resort, which American economists supported much more enthusiastically. However, while more supportive of the market mechanism and less inclined to intervention generally, Canadian economists were slightly more supportive of the redistributive role of government.

As we have seen, the popular assessment of economists - on the one hand this, on the other hand that - must be taken with a large grain of salt. True, there is discord on normative questions, but as to positive issues of price theory, there is great agreement. And why should this not be the case? Economists - like lawyers, plumbers, and doctors - have only their profession, and their specialized knowledge, in common. We would expect a core of agreement on matters of technical competency, but not on value judgments; this is the case, according to our findings. For example, virtually all economists, of whatever political stripe, see as harmful rent controls, tariffs, minimum wages and price controls.

Why, then, is the advice of economists on such issues so widely ignored? One answer, offered by the Public Choice School, is that there are many others besides economists who determine public policy on these issues. And most others, to be frank about this, have an axe to grind. Like it or not, we comprise but a small part of the decision-making apparatus in this regard.
But there is still room for optimism. Milton Friedman has stated 'We economists, all togeth$\mathrm{er}$, are probably responsible for the fact that tariffs are $1 \%$ less than they might have otherwise been. And because of this activity, we have probably earned our salaries a hundred fold'?

Perhaps more attention should be paid not to the issues on which economists disagree, but to those where we are in accord; and again, not to how far we still have to go to change public policy in a more sensible direction, but to how far we have come. At least in some cases, economists are like the Fenwickians in the movie 'The Mouse that Roared': pitifully few numerically, and yet having made a significant contribution to public policy making.

\section{Notes}

* We are pleased to acknowledge the unstinting efforts of Sandra Burrows in the compilation of the data. We are also grateful for the comments of members of the Fraser Institute Policy Workshop. Special thanks are due to Herber Grubel, David Hammes and Sally Pipes, all of whom, of course, have plenary absolution from remaining peccadilloes. As well, we wish to acknowledge a debt of gratitude to Kenneth Norrie, the editor of Canadian Public Policy - Analyse de Politiques and to three anonymous referees.

I The proposition set was the same as used by Frey et al. with the one exception that proposition 23 , relating to the rise in oil prices, was changed to specify a precise interval of time rather than 'the last five years'. The comparability of the samples is also affected somewhat by this passage of time since each of the samples was collected at a different point in time.

2 It was the intention that the survey be done on a double-blind basis so as to insulate both the researchers and respondents from the possibility of influence on the basis of the origin of the questions. Unfortunately, as is not infrequently the case, the eagerness of the mailing company to please thwarted this ambition. The company devised on its own initiative, despite our explicit instructions to the contrary, a franking blank to go into the postage meter which identified the Fraser Institute. Accordingly, we cannot claim double-blind status for the questionnaires which were dutifully sent in by the nearly 500 respondents to a blind post office box in Toronto. An unknown number would have seen the envelope and having seen it would have found the small franking mark. Since the potential failure of the double blind affected an unknown number of the questionnaires and the failure may have affected respondents in offsetting ways, we cannot say what the effect of the failure of double blind may have been.

3 A data set containing all the responses in machine 
readable form is available from the Fraser Institute, 626 Bute Street, Vancouver, B.C. V6E $3 \mathrm{M} 1$ at cost $\$ 55.00$ (including postage and handling).

4 In this regard we are following the lead set by Frey $e t a l$. (1984).

5 The following table shows the entropy calculations for particular response frequencies and may be helpful to interpret the reported entropy statistics.

\begin{tabular}{lllll}
\hline \multicolumn{3}{c}{ Response Frequency } & & $\begin{array}{l}\text { Relative } \\
\text { Entropy }\end{array}$ \\
\hline A & B & C & D & \\
\hline 0.25 & 0.25 & 0.25 & 0.25 & 1.0 \\
0.1 & 0.2 & 0.3 & 0.4 & 0.92 \\
0.33 & 0.33 & 0.33 & 0 & 0.79 \\
0.5 & 0.5 & 0 & 0 & 0.5 \\
0.1 & 0.1 & 0.8 & 0 & 0.46 \\
0.75 & 0.25 & 0 & 0 & 0.41 \\
1.0 & 0.0 & 0.0 & 0.0 & 0.0 \\
\hline
\end{tabular}

Where A,B,C,D are the response categories, generally agree, agree with reservation, disagree and no answer.

$6 \mathrm{It}$ is possible to interpret this reply not as a finding of market failure, but as a buttress against fraudulent practices, which are not, strictly speaking, part of the free marketplace.

7 For those who find a table casier to follow, this taxonomy may be of help:

\begin{tabular}{lll}
\hline & \multicolumn{1}{c}{ Can } & \multicolumn{1}{c}{ Should } \\
\hline Micro & $1,4,5,7,15,17$ & $11,21,26,27$ \\
Macro & $3,9,12,20,25$ & $2,8,13,16,18,22$ \\
\hline
\end{tabular}

8 Whether or not the answers of female economists are significantly different from those of males is an interesting issue. But the group is so small, and the women are so relatively young, that more work is necessary to address this issue. For research on other aspects of the implications of gender-related differences, see Block and Walker $(1982 ; 1985)$.

9 Paraphrase of a statement made at the Los Angeles meeting of the Western Economic Association, 1985.

\section{References}

Block, Walter and Michael Walker (eds.) (1982) Discrimination, Affirmative Action and Equal Opportunity (Vancouver: The Fraser Institute).

(1985) Focus on Employment Equity: A Critique of the Abella Royal Commission on Equality and Employment (Vancouver: The Fraser Institute).

Frey, Bruno S., Werner W. Pommerehne, Friedrich Schneider and Guy Gilbert (1984) 'Consensus and Dissension Among Economists: An Empirical Inquiry,' American Economic Review, December, 74:5:986-94.

Friedman, Milton (1953) Essays in Positive Economics (Chicago: University of Chicago Press).

Kearl, James R. et al. (1979) 'A Confusion of Economists?,' American Economic Review Proceedings, May, 69:28-37. 